\title{
DETERMINATION OF TIME OF DEATH BASED ON BLOOD RING FORMATION AND RNA DEGRADATION
}

\author{
Siti Eliza Hasningsih ${ }^{1 *}$, Niken Satuti Nur Handayani ${ }^{{ }^{*}}$, Putut Tjahjo Widodo ${ }^{2 *}$ \\ ${ }^{1}$ Gadjah Mada University, Bulaksumur, Yogyakarta, Indonesia 55281 \\ *Email: siti.eliza.h@mail.ugm.ac.id, niken_satuti@ugm.ac.id \\ ${ }^{2}$ QC Laboratory of PCR Covid PT. HENINDO; Member of Asia Pacific Forensic \\ Science Networking, Indonesia, Jawa Barat, 16475 \\ *Email: pututtw@yahoo.com
}

\begin{abstract}
Time of death (TOD) determination is crucial in criminal cases. The method used to determine the TOD so far is only based on the state of the corpse found, therefore a new method is needed to improve the accuracy of the TOD determination. This study aims to determine the TOD based on a new method, namely the formation of blood rings and RNA degradation. Blood is commonly found in crime scenes. Blood consists of liquid part that is plasma and cellular part consisting of erythrocytes, leukocyte, and thrombocytes. The composition of blood as a liquid that contains dissolved solids makes the drops of dried blood forming "coffee ring effect", which is a ring-like form on the perimeter of a blood drop. Coffee ring effect is used as an indicator of time by looking at the thickness of the ring formed from the perimeter of the blood drop to the middle which increases with time. RNA degradation was observed using Peptidylprolyl isomerase A (PPIA) gene. The PPIA gene is found in leukocyte and is used to see the degradation of RNA per 30 minutes period using the RT-PCR and qPCR methods. Degradation was observed by comparing the cycle threshold (ct) value of the standard curve with the ct value of the samples per unit time. TOD could be determined by the percentage of the blood ring thickness up until 120th minutes, and by observing the degradation of RNA until the 60th minute, after that the RNA had completely degraded.
\end{abstract}

Keywords: time of death, coffee-ring effect, PPIA gene, RNA degradation, RT-qPCR

\section{INTRODUCTION}

Timeliness in determining the time of death (TOD) is crucial to determine a person's involvement based on the suitability of the alibi possessed with the TOD. So far, common methods of determining TOD are: (1) cooling the body; (2) rigor mortis; (3) putrefaction; (4) chemical processes (metabolism, autolysis, and diffusion); and (5) entomology (Madea, 2016). Determinations based on the state of the corpse have low estimated timeliness. Novel and more efficient methods are needed to improve the estimation of the accuracy of determining the TOD quickly as the increase of estimation accuracy of TOD are much more efficient by considering the influencing factors (Henssge, 2007).

One source of biological evidence commonly found at a crime scene is blood. Blood is commonly used as an identification tool to determine a person's identity (Virkler, 2009). Blood consists of a fluid part called plasma, and a cellular part consisting of red blood cells (erythrocytes), white blood cells (leukocytes) and platelets (thrombocytes) (Kulstein, 2018). 
The composition of blood as a liquid containing dissolved solids makes drops of blood fluid can be used as an indicator of time in determining TOD based on the coffee ring effect. Liquids with dissolved solids form a coffee ring effect, which is when the liquid dries out and leaves a ring mark on the peripheral of the drop. The blood drop dries up on the same principle, the outer part of the blood drop dries first compared to the middle so that it resembles a ring. The blood ring that is formed is then used to determine the time since the blood fluid is dripped until the ring is formed and dries up (Deegan, 2000).

The drying process of drop of blood was demonstrated by Brutin (2011) by observing ring formation during blood drop drying. The research on blood drops by Brutin was done to understand the formation of blood rings. The research shows the evaporation process that occurs in blood drops, which are liquids with dissolved substances. (Deegan, 1997).

Blood has groupings based on antigenic substances on red blood cells which cause differences in blood groups. The ABO blood grouping system is determined based on 4 molecules determining blood group, namely: 1) D-galactose; 2) $\mathrm{N}$ acetylgalactosamine;

3) $\mathrm{N}-$ acetylglucosamine; and 4) L-fucose (Murray, 2009). These molecules attach to red blood cells and produce antigens which then determine blood group. The ABO blood grouping system has different structure in molecular and antigens, so it is necessary to look at its effect in the formation of blood rings. Blood drops can be found anywhere at the crime scene, hence a comparison is needed for the blood drops found in common different surface, such as ceramic tiles and glass.

Blood contains genetic material in the form of RNA and DNA found in white blood cells. RNA has great potential as a determinant of the TOD. Research by Bauer (2003) showed a relationship between mRNA quantity or RNA degradation and the postmortem interval. The quantity of RNA is shown to be closely related to the TOD as RNA degradation can be seen by hours interval (Bauer, 2007). A genetic approach to determine the TOD is by looking at the RNA degradation in the blood drops found. The gene used to see the degradation of RNA is the PPIA gene, which is a housekeeping gene. RNA degradation was tested using quantitative analysis with quantitative PCR (SampaioSilva 2013). Quantitative PCR has fluorescent labelling that shows numbers of amplified genetic material after accumulated in the reaction in real time after each amplification cycle has finished (Bustin, 2009)

\section{RESEARCH METHODS Materials}

The equipment used in this study was a digital thermometer to measure room temperature, a calliper to measure the outer and inner diameter in blood drops, micropipettes, and tips to drip blood onto the media, gloves, micro tube, PCR tube, qPCR tube, vortex, centrifuge, autoclave and ultraviolet lamp for tool sterilization. Thermo cycler for Reverse Transcription PCR reactions, BIO-RAD CFX 96 for Quantitative PCR reactions, and nanodrops to see the quality of RNA. 
The materials used were human blood samples of blood types A, B, $\mathrm{AB}, \mathrm{O}$. Primer sets of PPIA genes (peptidylprolyl isomerase A) consists of forward primer GTTCTTCGACATTGCCGTCG, and reverse primer AAATTTTCTGCTGTCTTTGGGA CC. Primers are designed based on the mRNA sequence of the PPIA gene (NM_021130.5). primer was designed using primer BLAST from NCBI.

\section{Methods}

\section{Blood Sampling}

The blood used in this research was taken according to the ethical clearance issued by the UGM Faculty of Medicine (No. Ref. KE / FK / 0412 / EC / 2020). The volunteers filled out informed consent form before the

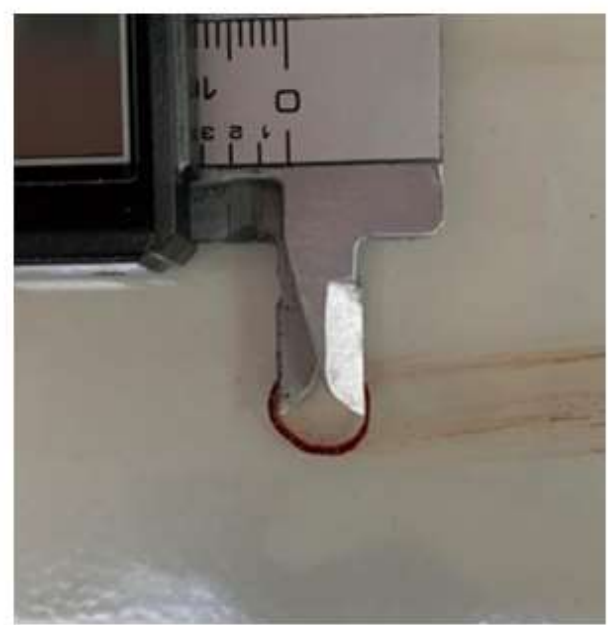

a blood collection process is carried out. The process was done by a qualified health analyst. A $5 \mathrm{ml}$ blood sample was taken once per subject and put into a tube without anticoagulant.

\section{Blood Ring Observation}

Blood ring observation was carried out using two comparison factors: blood type and media. The blood types used for the study are types $\mathrm{A}, \mathrm{B}, \mathrm{AB}$, and $\mathrm{O}$. The medias used are glass and ceramic surfaces. There are 5 observation times $(0,30$, 60,90 , and 120 minutes) which was done three times. Each blood group was dropped as much as $50 \mu \mathrm{l}$ on the glass and ceramic surfaces. The blood drops were rubbed in one direction using a tissue, then the outer diameter and inner diameter were measured using a calliper as shown in Figure 1.

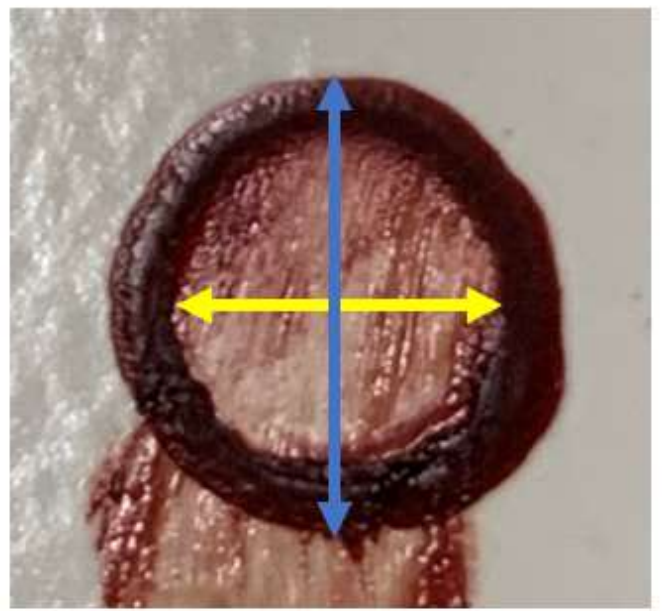

b

Figure 1. Measurement of the diameter of blood drops; (a) Measurement of the diameter of blood drops using a caliper; (b) Yellow arrow: inner diameter (ID) of blood ring, blue arrow: outer diameter (OD) of blood ring.

\section{RNA extraction}

RNA extraction from blood drop was performed using TRIsure ${ }^{\mathrm{TM}}$ Reagent. The steps were carried out in accordance with the protocol of
TRIsure ${ }^{\text {TM }} \quad$ Reagent with modifications: (1) Homogenization, $50 \mu \mathrm{l}$ of piped blood drops. The blood that has not dried or the blood that has dried is added with $100 \mu \mathrm{l}$ of 
TRIsure ${ }^{\mathrm{TM}}$ for resuspension. Resuspension is done by up and down using a micropipette. The mixture in the suspension form was pipette and placed into a tube containing $100 \mu \mathrm{l}$ of TRIsure ${ }^{\mathrm{TM}}$; (2) Phase separation, the samples were incubated for 5 minutes at room temperature, after which $30 \mu \mathrm{L}$ of chloroform was added, the tube was tightly closed and inverted by hand for 15 seconds. Samples were incubated for 3 minutes at room temperature, then incubated at $-20^{\circ} \mathrm{C}$ for 10 minutes. After that, samples were centrifuged for 15 minutes@12,000 g, the samples were separated into three layers, dark red at the bottom of the tube, interphase in the middle of the tube, and the water phase at the top of the tube; (3) RNA precipitation, the water phase containing RNA was transferred into a new tube. A total of $75 \mu \mathrm{l}$ of isopropanol was added to the tube. Samples were incubated for 10 minutes at room temperature, then incubated at $-20^{\circ} \mathrm{C}$ for 10 minutes. After that, the sample was centrifuged for 10 minutes $12,000 \mathrm{~g}$; (4) RNA washing, the supernatant was removed with a micropipette, the pellets were resuspended in $150 \mu 1$ $75 \%$ ethanol, the sample vortex, then the samples were centrifuged for 5 minutes $7,500 \mathrm{~g}$ at $4^{\circ} \mathrm{C}$; (5) Redissolve RNA, alcohol was removed with a micropipette. RNA pellets were dried and then resuspended in $13 \mu \mathrm{l}$ of RNAse-free water by pipetting up and down. Samples were incubated at a water bath temperature of $55-60^{\circ} \mathrm{C}$ for 10 15 minutes. The extracted RNA concentrations were then immediately measured using a nanodrop to determine the concentration of RNA that will be synthesized into complementary DNA (cDNA).

\section{Reverse-Transcription PCR}

The extracted RNA was then treated with Reverse-Transcription PCR to obtain cDNA. Synthesis of cDNA was carried out by following the protocol from the ReverTra Ace $\AA$ qPCR RT Master Mix kit, namely: (1) denaturation of RNA, the RNA solution was incubated at $65^{\circ} \mathrm{C}$ for 5 minutes, then stored in ice; (2) preparation of the reaction solution: $5 \mathrm{x}$ mastermix $2 \mu \mathrm{l}$, template RNA as much as $150 \mu \mathrm{g}$ per reaction, and added nuclease-free water until the total volume of the solution reaches $10 \mu \mathrm{l}$. The RT-PCR reaction consisted of: (1) incubation at $37^{\circ} \mathrm{C}$ for 15 minutes; (2) incubation at $50^{\circ} \mathrm{C}$ for 5 minutes; (3) heating at $98^{\circ} \mathrm{C}$ for 5 minutes; (4) the solution is stored at $20^{\circ} \mathrm{C}$.

\section{Making Standard Curve}

The cDNA sample synthesized from the highest concentration of RNA from minute 0 was chosen to be the standard curve template. The steps to get a standard curve are:

1) Amplification of the PPIA gene. The samples were amplified using the MyTaq ${ }^{\text {TM }}$ HS Red Mix PCR kit. The reaction was carried out by mixing 10 $\mu \mathrm{l}$ of template cDNA, $10 \mathrm{mMol}$ of forward and reverse PPIA primers each $1.5 \mu 1,10 \mu 1$ of MyTaq ${ }^{\text {TM }}$ HS Red Mix, and $27 \mu$ l of nuclease-free water into PCR tube. The mixture was homogenized using vortex and spun down using a microfuge. The amplification reaction with a thermocycler was 35 cycles, the 
initial denaturation temperature was $95^{\circ} \mathrm{C}$ for 1 minute. Denaturation at $95^{\circ} \mathrm{C}$ for 15 seconds, annealing at $57.4^{\circ} \mathrm{C}$ for 10 seconds, and extension at $72^{\circ} \mathrm{C}$ for 15 seconds. Samples were stored at $4^{\circ} \mathrm{C}$.

2) Gel purification. PCR products were electrophoresed on $1.8 \%$ agarose gel. The PCR product was put into 5 wells of $20 \mu 1$ gel each. The electrophoresis process was carried out for 50 minutes at a voltage of 50 volts. Agarose gel was observed by UV light. The agarose gel was then purified using the GenepHlow TM Gel/PCR Kit from Geneaid. The portion of the agarose gel containing the target DNA band was cut and inserted into a $1.5 \mathrm{ml}$ micro tube. Add $500 \mu \mathrm{l}$ of gel / PCR buffer and vortex micro tube. The solution was then incubated at $57^{\circ} \mathrm{C}$ for 15 minutes, the micro tubes were inverted every 2-3 minutes during incubation. DFH Column is placed into a $2 \mathrm{ml}$ collection tube, then $800 \mu \mathrm{l}$ of the sample solution is added to the DFH Column. Samples were centrifuged at $16,000 \mathrm{~g}$ for 30 seconds. The liquid that passes through the filter is discarded, then the DFH Column is put back into the $2 \mathrm{ml}$ collection tube. A total of $400 \mu 1$ of W1 Buffer was added to the DFH column and then centrifuged at $16,000 \mathrm{~g}$ for 30 seconds. The liquid that passes through the filter is discarded, then the DFH Column is put back into the $2 \mathrm{ml}$ collection tube. A total of $600 \mu \mathrm{l}$ of Wash Buffer was added to DFH Column and allowed to stand for 1 minute at room temperature. Samples were centrifuged at $16,000 \mathrm{~g}$ for 30 seconds. The liquid passing through the filter is removed and the DFH
Column is put back into the $2 \mathrm{ml}$ collection tube. Samples were centrifuged at 16,000 g for 3 minutes, then the dry DFH column was transferred to a $1.5 \mathrm{ml}$ microtube. A total of $40 \mu \mathrm{l}$ of heated elution buffer $\left(70^{\circ} \mathrm{C}\right)$ was added to the centre of the DFH Column matrix. The sample were incubated for 2 minutes at room temperature so that the elution buffer was fully absorbed, then the samples were centrifuged at $16,000 \mathrm{~g}$ for 2 minutes. The pure cDNA sample in the elution buffer was then calculated using nanodrop concentration. The concentration of pure cDNA from nanodrop is used to obtain the copy number of PPIA gene using the copy number calculator from the scienceprimer.com web page.

3) Making cDNA Serial Dilution. The dilution was done in 5 levels. Dilutions were made by adding $1 \mathrm{ul}$ of pure cDNA to $49 \mu$ l of nuclease-free water. This serial dilution then amplified to detect the copy number from each dilution.

4) Quantitative PCR. Quantitative PCR was done using BIO-RAD CFX 96 and reagent from THUNDERBIRD® SYBR® ${ }^{\circledR}$ qPCR Mix. The repetition set of the standard curve solution was made 1 time. The steps are carried out according to the protocol of the THUNDERBIRD® SYBR ${ }^{\circledR}$ qPCR Mix: (1) a set of reaction solutions consisting of 10 $\mathrm{mMol}$ of forward and reverse primers are prepared $0.6 \mu \mathrm{l}$ each, THUNDERBIRD® ${ }^{\circledR}$ SYBR ${ }^{\circledR}$ qPCR Mix $10 \mu \mathrm{l}, 3 \mu \mathrm{l}$ of cDNA, and added with nuclease free water until the volume reaches $20 \mu \mathrm{l}$; (2) The qPCR process begins with pre-denaturation 
at $95^{\circ} \mathrm{C}$ for $20-60$ seconds, then denaturation at $95^{\circ} \mathrm{C}$ for 15 seconds, and extension at $60^{\circ} \mathrm{C}$ for $30-60$ seconds with 40 cycles.

\section{RNA Degradation Observation}

Samples were taken from blood drops with time periods of 0 minutes, 30 minutes, 60 minutes, 90 minutes, and 120 minutes. Each sample was extracted RNA using TRIsure ${ }^{\mathrm{TM}}$.

1) Reverse-Transcription PCR. The extracted RNA was then reversetranscripted using Reverse Transcription-PCR using Thermocycler to obtain complementary DNA (cDNA). Synthesis of cDNA was done by adding reagents from ReverTra Ace ${ }^{\circledR}$ qPCR RT Master Mix with the process: (1) denaturing RNA, incubating the RNA solution at $65^{\circ} \mathrm{C}$ for 5 minutes, then storing it in ice; (2) preparation of the reaction solution: 2 $\mu l$ of $5 x$ mastermix, 150 ng of RNA template, added with nuclease-free water until the total volume of the solution reaches $10 \mu \mathrm{l}$; (3) incubation at $37^{\circ} \mathrm{C}$ for 15 minutes; (4) heated at $98^{\circ} \mathrm{C}$ for 5 minutes, and: (5) storage at $4^{\circ}$.

2) Quantitative PCR. Quantitative PCR was carried out using BIO-RAD CFX 96 with reagent and protocol from THUNDERBIRD® ${ }^{\circ}$ SYBR $®$ qPCR Mix. The THUNDERBIRD® SYBR ${ }^{\circledR}$ qPCR Mix protocol are: (1) a set of reaction solutions consisting of $10 \mathrm{mMol}$ of forward and reverse primers each $0.6 \quad \mu$, THUNDERBIRD® ${ }^{\circledR}$ SYBR $®$ qPCR Mix $10 \mu 1$, cDNA as much as $2 \mu 1$, and added nuclease free water until it reaches a volume of $20 \mu \mathrm{l}$; (2) The
qPCR process begins with predenaturation at $95^{\circ} \mathrm{C}$ for $20-60$ seconds, then denaturation at $95^{\circ} \mathrm{C}$ for 15 seconds, and extension at $60^{\circ} \mathrm{C}$ for 30-60 seconds with 40 cycles.

\section{Data Analysis}

Blood ring thickness data were analyzed by making an average blood ring thickness of 2 media per study period. The data obtained were the average thickness of the blood rings from 2 different media and 4 time periods of sample observation.

Analysis of the percentage of blood ring area was done by calculating the total blood drop area (TA) and the area of rubbed blood (RA), obtained from the outer diameter (OD) and inner diameter (ID) data, respectively. The percentage of the area of the blood ring is calculated by the formula: PRA $=($ TA-RA $) / T A \times 100 \%($ PRA: Percentage of blood ring area, TA: The total area of the blood drop, RA: Area of rubbed blood drop).

Data on the percentage of blood ring area of the four blood groups were averaged for glass and ceramic media, respectively. The average percentage area of the blood rings for glass and ceramic media are graphed using Excel to visualize the data and obtain the equation $y=m x+b$. The equation obtained can be used to determine the TOD by entering the percentage value of the blood ring area as the y value.

RNA degradation was analyzed using absolute quantification methods. Absolute quantification methods require standard curve. The sample that was used to make standard curve was calculated using the copy number calculator 
application provided by the scienceprimer.com by inserting the amplicon base pair length and the cDNA concentration. The cycle threshold (ct) of the test sample is compared with a standard curve with a known copy number. The absolute quantification standard curve produces a graph in the form of the value of ct on the $\mathrm{Y}$ axis and the copy number on the $\mathrm{X}$ axis. The equation formula obtained from the standard curve $(y=m x+b)$ is used to find the copy number of the test sample. Determination of the copy number of the test sample is done by entering ct as the $x$-value into the equation formula obtained from the standard curve, so that the number of RNA copy numbers, the y value, can be determined in each tested sample.

\section{RESULT AND DISCUSSIONS}

1. Result of Blood Ring Thickness Measurement

The results of measuring the thickness of the blood rings in this study showed that the blood rings were getting thicker with time. This result is in accordance with Laan's (2016) research, the blood drops dried from the perimeter of the circle to the centre. The blood drops are rubbed, the middle of the wet blood drops is absorbed by the tissue and leaves a ring-shaped perimeter.

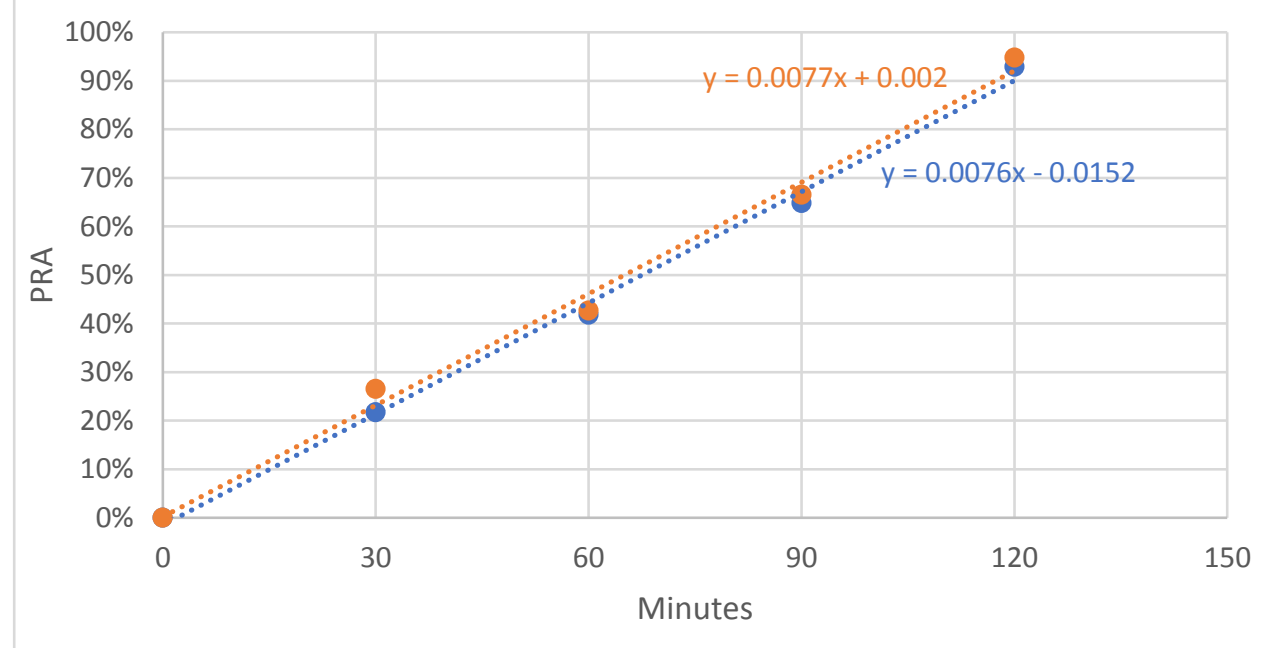

Figure 2. The percentage ratio of the blood ring area to blood drops area on ceramic and glass media per 30 minutes from minute 0 to 120 .

The graph shown in Figure 2 is the average percentage of the blood ring area (PRA) of blood to the area of drops of blood for each blood group to time on glass and ceramic media. The percentage ratio of the area of the blood ring to the area of blood drops obtained from the study resulted in the equation $\mathrm{y}=0.0076 \mathrm{x}$ 0.0152 on glass and $\mathrm{y}=0.0077 \mathrm{x}+0.002$ on ceramic. This equation can be used to determine the TOD of blood drops found in airconditioned rooms with a temperature range of $28 \pm 0.5^{\circ} \mathrm{C}$.

\section{RNA Extraction}

The purity of extracted RNA was observed using nanodrop. Then the RNA was Reverse Transcripted to 
form cDNA. Quantification result by nanodrop shows both whole and degraded RNA (Anderson, 2010) so that RNA quantification using qPCR is needed. Reverse-Transription PCR process was done by using $150 \mathrm{ng}$ RNA per reaction. This concentration amount was used because it fits within the range of RNA that can be amplified using ReverTra Ace Kit (1 pg $-1 \mu \mathrm{g})$. Reverse-Transcriptation
PCR only amplified whole and unfragmented (Antonov, 2005), so the amplification results are able to indicate RNA degradation.

\section{Standard Curve}

RNA degradation is determined by comparing the ct value of the test sample against a standard curve. The unit obtained from $\mathrm{qPCR}$ is the ct value.

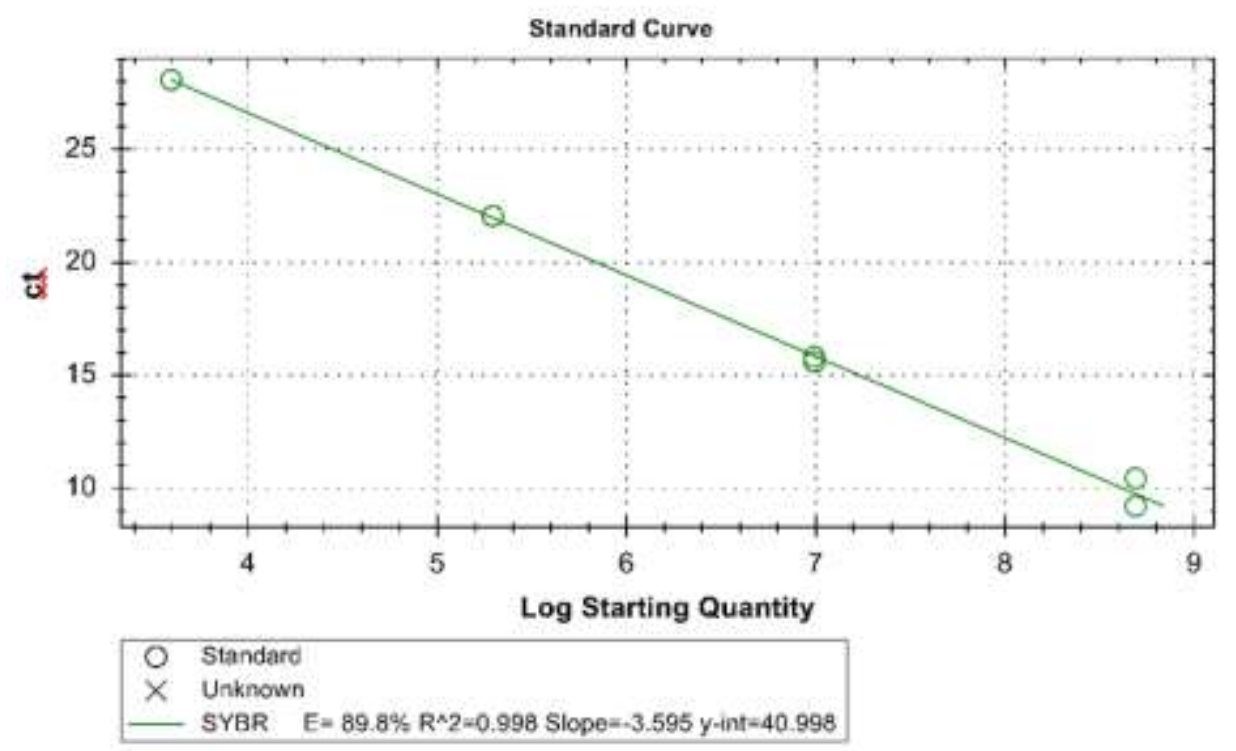

Figure 3. PPIA Gene Standard Curve

The standard curve of the PPIA gene were made by making a serial dilution of cDNA with a copy number of 490,700,000 per microliter sample, after which the dilution was amplified using qPCR. The amplification result of this graded dilution is then referred to as the standard curve. The standard curve ct value is then calculated to obtain the equation $\mathrm{y}=-3.595 \mathrm{x}+$ 40,998 . This equation is used to find the copy number of the test sample.
4. Absolute Quantification Result

The data obtained is in the form of the ct value of the qPCR amplification. The data analyzed were ct values taken from 3 biological repetitions and 2 technical repetitions. The value of ct is entered into the equation that has been created based on the standard curve, $y=-$ $3.595 x+40,998$, by inserting the value of ct as $x$. From this equation. the PPIA gene copy number decreases over time from the 0th minute to the 120th minute, as shown in Figure 4. 

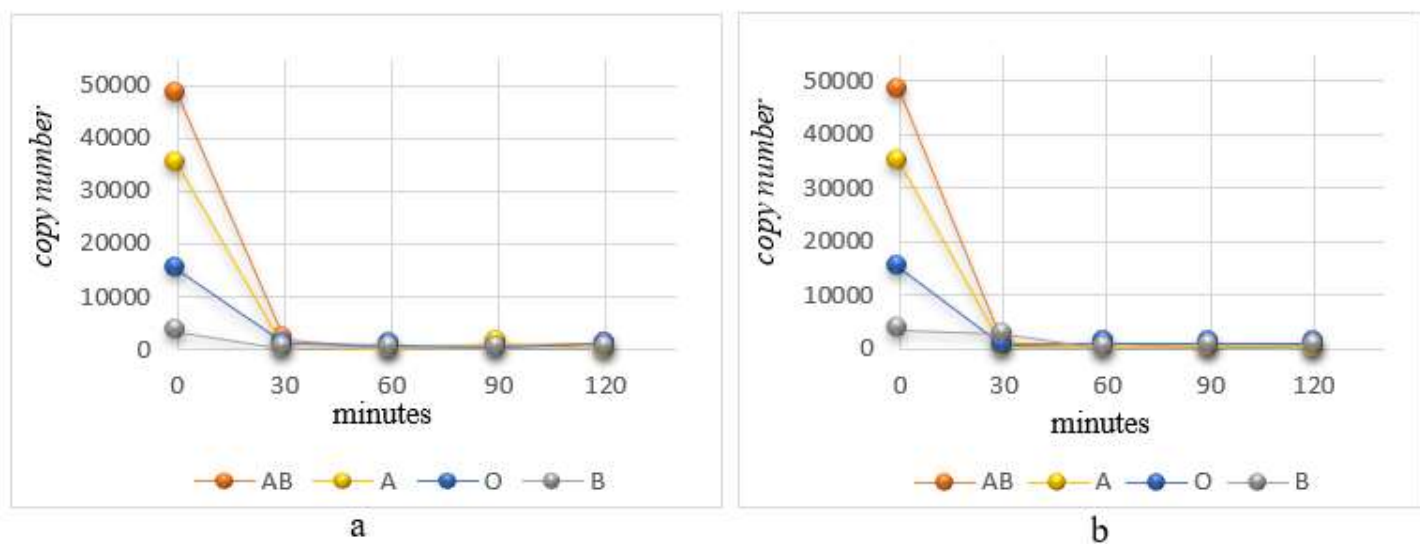

Figure 4. Decrease in PPIA gene copy number per blood group on (a) glass and (b) ceramic.

Decreased copy number of the PPIA gene represents the RNA that is degraded over time. The order of blood groups with the highest to lowest copy numbers on glass and ceramic media has the same trend, with the highest copy number belonging to blood group $\mathrm{AB}$, followed by A, O, and blood group B. This shows the PPIA gene titer owned by each group blood may vary, so it is necessary to enumerate the PPIA genes for each blood group. All blood groups have a decreased copy number until the 60th minute. after 60 minutes, no degradation was observed because the RNA had completely degraded.

The formation of blood rings and RNA degradation have a correlation, the blood ring thickens as the RNA degradation increases. At 60 minutes, the RNA was completely degraded, with a blood ring formation percentage of $42.5 \%$. If the percentage of blood ring formation is more than $42.5 \%$, the determination of the TOD can only be done by using the equation for the percentage of blood ring formation.

\section{CONCLUSION}

Blood type and media have no effect on RNA degradation. Blood ring analysis data yields the percentage of blood ring area. The percentage of blood ring area increases with time. RNA degradation is getting higher over time. The percentage of blood ring area with the copy number of PPIA gene shows an inversely related relationship, as the percentage of blood ring area increases, the copy number decreases. RNA of all blood groups was totally degraded at 60 minutes, observed from a decrease in the copy number. The TOD can be determined based on the analysis of blood ring formation and RNA degradation up to the 60th minute.

\section{REFERENCES}

[1] Anderson, M. A. et al., 2010. Reliable Gene Expression Measurements from Fine Needle Aspirates of Pancreatic Tumors. The Journal of Molecular Diagnostics, 12(5), 566-575. doi:10.2353/jmoldx.2010.0901 07

[2] Antonov, J. et al., 2005. Reliable gene expression measurements from degraded 
RNA by quantitative real-time PCR depend on short amplicons and a proper normalization. $L a b$ Invest 85, 1040-1050 https://doi.org/10.1038/labinve st. 3700303

[3] Bauer, M. et al., 2003. Quantification of mRNA Degradation as Possible Indicator of Postmortem Interval-A Pilot Study. Leg Med (Tokyo) 5: 220-227.

[4] Bauer, M., 2007. RNA in Forensic Science. Forensic Science International: Genetics 1 69-74

[5] Brutin, D. et al., 2011. Pattern Formation in Drying Drops of Blood. Journal of Fluid Mechanics. 667: 85-95.

[6] Bustin, S.A. et al., 2009. The MIQE Guidelines: Minimum Information for Publication of Quantitative Real-time PCR Experiments. Clinical Chemistry. 55 (4): 611-22.

[7] Deegan, R.D. et al., 1997. Capillary Flow as the Cause of Ring Stains from Dried Liquid Drops, Nature 19. 827-829.

[8] Deegan, R.D., 2000. Pattern Formation in Drying Drops, Phys. Rev. E61475-485.
[9] Henssge, C. \& Madea, B., 2007. Estimation of The Time Since Death. Forensic Science International. 165: 182-184

[10] Kulstein, G., \& Wiegand, P., 2018. Comprehensive Examination of Conventional and Innovative Body Fluid Identification Approaches and DNA Profiling of Laundered Blood-and Saliva-Stained Pieces of Cloths. International Journal of Legal Medicine, 132(1), 67-81.

[11] Laan, N. et al., 2016. Morphology of drying blood pools. Forensic Science International. 267. 104-109.

[12] Madea, B. 2016. Methods for Determining Time of Death. Forensic Sci Med Pathol 12: 451-485

[13] Murray, R.K., 2003. Illustrated Biochemistry, 27th Edition. McGraw-Hill. 645 - 646

[14] Sampaio-Silva, F. et al., 2013. Profiling of RNA Degradation for Estimation of Post Morterm Interval. PLoS ONE 8(2): e56507.

Doi.x10.1371/journal.pone.005 6507 